J. Craig Venter

IN STITUTE

Final Progress Report

The Tapestry of Life: Lateral Transfers of Heritable Elements - Scientific Meeting December 12-13, 2005

Grant No.: DE-FG02-06ER64153

Principal Investigator: Claire M. Fraser, Ph.D. 


\section{Arthur M. Sackler \\ $C O L L O Q U I A$ \\ OF THE NATIONAL ACADEMY OF SCIENCES \\ The Tapestry of Life: \\ Lateral Transfers of Heritable Elements}

December 12-13, 2005

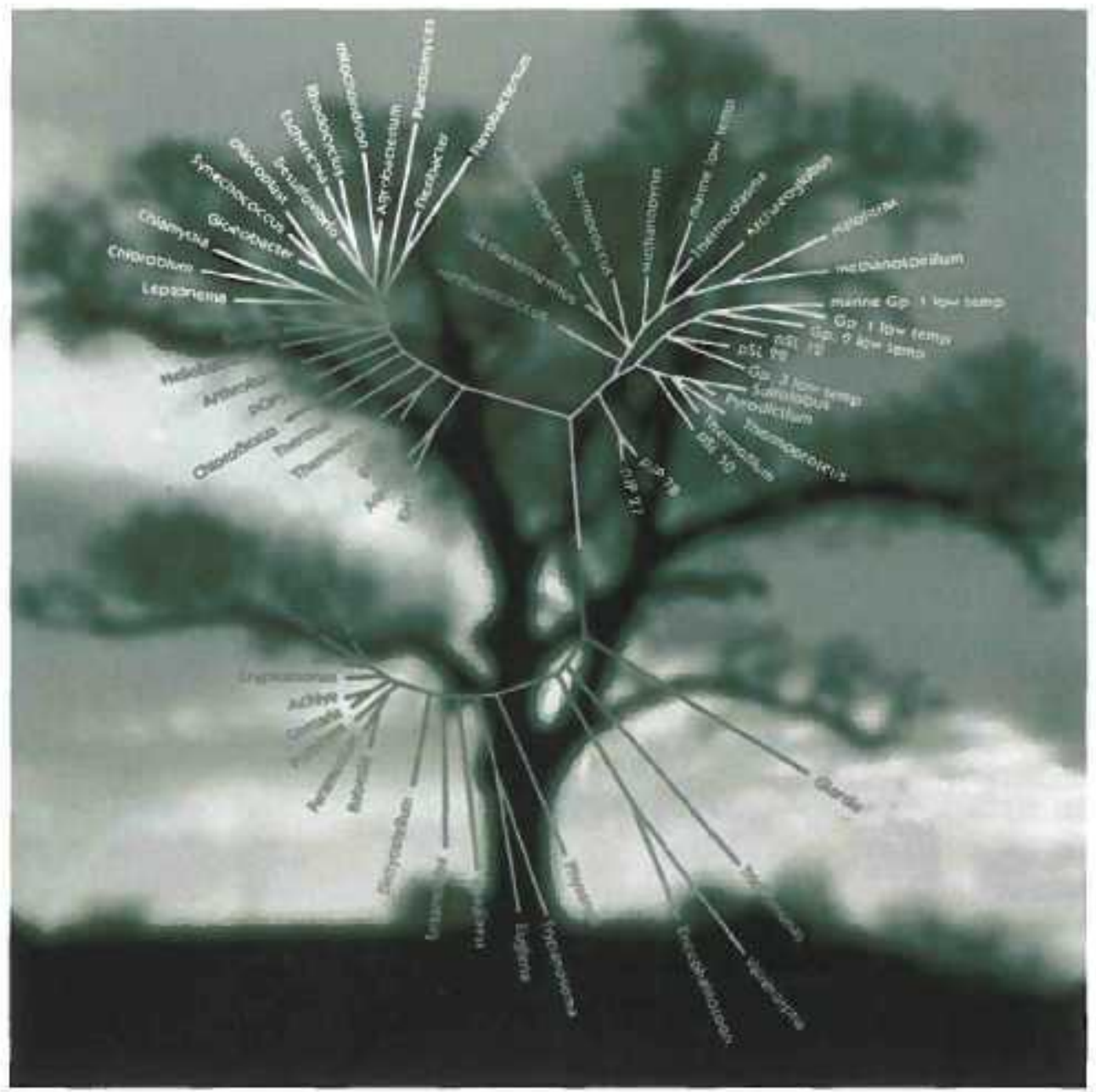

Beckman Center of the National Academies

Irvine, California

Organized by Siv Andersson, Jonathan Eisen,

Claire Fraser, and Jeffrey Gordon 

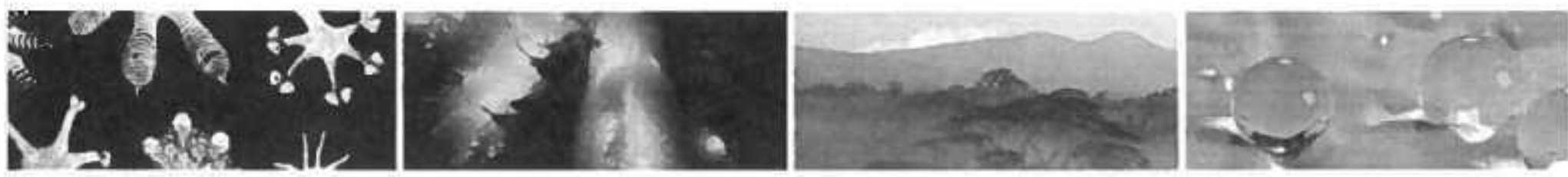

Member Login | Login help

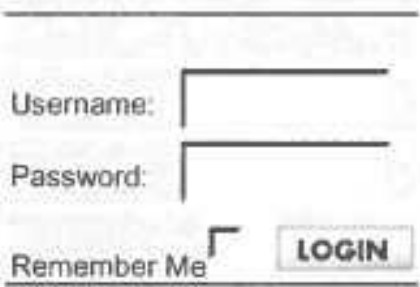

- Home

About the NAS

Members

- Nomination and Election

- Awards

Publications

National Academies Studies

\section{ACTIVITIES}

Koshland Science Museum

Evolution Resources

Crop Plants: Apr 3.5

Neurosciences Nov. 16-18

Kavil Frontiers of Science

Science Classics

Keck Futures Initiative

Exhibitions and Cultural

Programs

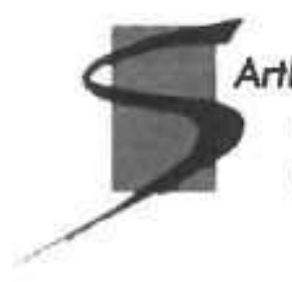

Arthur M. Sackler

$C \bigcirc L L \bigcirc Q U \mid A$

OF THE NATIONAL ACADEMY OF SCIENCES

\section{Tapestry of Life: Lateral Transfers of Heritable Elements}

Organizers: Siv Andersson, Jonathan Eisen. Claire Fraser, and Jeffrey Gordon

Co-Chairs: Claire Fraser and Jeffrey Gordon

Beckman Center, Irvine, California

December 12-13, 2005

Final Program and Presentations

Meeting Overview

The Sackler Colloquium The Tapestry of Life: LateraI Transfers of Heritable Elements was held on December 12-13, 2005. What Darwin saw as a tree of life descending in a linear fashion, is now more accurately seen as a tapestry of life, an anastomosing network, with important lateral transfers of heritable elements among parallel lines of Jescent. These transfers range in complexity from small insertion sequences, to whole genes, gene islands, and portions of whole genomes which may be combined in symbiogenesis. The colloquium brought together researchers, empirical and theoretical, working at all levels on genomics, comparative genomics, and metagenomics to dentify common and differentiating features of lateral gene transfer and to examine their implications for science and for human concerns.
Related Links:

Arthur M. Sackler

Biography

Completed Colioquia:

Biological Sciences

Physical Sciences

Social Sciences
National Academy of

Sciences

500 Fifth Street, NW

Washington, DC 20001

Terms of Use and Privacy

Policy

Contact Us | Site Map

Printer Friendly Version 


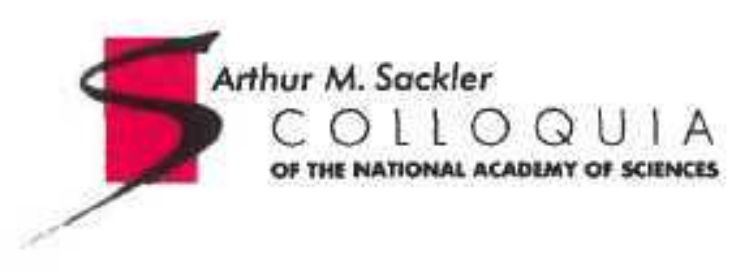

\title{
THE TAPESTRY Of LifE: LATERAL TRANSFers of HeRItABle Elements
}

\author{
December 12-13, 2005 \\ Beckman Center of the National Academies, Irvine, California \\ Organized by Siv Andersson, Jonathan Eisen, Claire Fraser, and Jeffrey Gordon \\ Co-Chairs: Claire Fraser and Jeffrey Gordon \\ FINAL PROGRAM
}

Sunday, December 11

6:00-8:00pm Registration and Welcome Reception, Hyatt Regency Newport Beach

Monday, December 12

7:15am \& 7:45am Buses leave Hyatt Regency Newport Beach for Beckman Center

7:15am Poster setup in Huntington Room

7:30am Registration and Buffet Breakfast, Dining Room

8:45am Greetings, Jeffrey Gordon (Washington University of Medicine)

Introductory comments about purpose/goals of meeting

Session I: Mechanisms and Experimental Studies of LGT

Chair:

Abigail Salyers (University of Illinois)

9:00am

Forest Rohwer (Scripps), Global Phage Diversity and the Movement of Genes

9:30am Penny Chisholm (MIT), Prochlorococcus Diversity: How to Dominate the Oceans with 2000 Genes

10:00am Abigail Salyers (University of Illinois), LGT in the Human Colon: How Much and How Important?

10:30am Break

11:00am Marlene Belfort (Wadsworth Center, NYS Department of Health), Molecular Machinery for Lateral Transfer of Introns

11:32am Poster Abstract Presentation: Michael Miller (Stanford University), Natural Transformation as a Source of Diversity Among Vibrio Cholerae Isolates

12:00pm-1:00pm Buffet Lunch, Dining Room 


\section{Session II: Methods of Detection}
Chair:
Jeffrey Lawrence (University of Pittsburgh)
$1: 15 \mathrm{pm}$
Jeffrey Lawrence (University of Pittsburgh), Measuring Non-Random LGT Among Bacterial Lineages
$1: 45 \mathrm{pm}$
Herve Philippe (University of Montreal), Are Horizontal Gene Transfers the Most Disturbing Limitation for Inferring Prokaryotic Phylogeny?
2:15pm
Christos Ouzounis (European Bioinformatics Institute), Genome Conservation and the Net of Life
$2: 45 p m$
Break
$3: 15 \mathrm{pm}$
James Lake (UCLA), The Ring of Life and the Origin of Eukaryotes
$3: 45 \mathrm{pm}$
Poster Abstract Presentation: Kaiyuan Shi (University of Connecticut), Parametric Bootstrap Analyses of Bacterial 16SrRNA Mosaicism
$4: 15 p m-5: 15 p m$
Panel discussion featuring speakers from Sessions I and II
$5: 30 \mathrm{pm}$
Poster Session in Huntington Room
7:00pm
Dinner in Atrium
8:00pm
Buses leave Beckman Center for Hyatt Regency Newport Beach

Tuesday, December 13

7:15am \& 7:45am Buses leave Hyatt Regency Newport Beach for Beckman Center

7:30 am Buffet Breakfast, Beckman Center Dining Room

\section{Session III: Case Studies}

Chair Siv Andersson (University of Uppsala)

Goals: More in depth presentations of illustrative/provocative case studies of LGT

8:30am Jeffrey Palmer (Indiana University), Plant Mitochondrial Genomes: Unexpected Bounties of Lateral Gene Transfer

9:00am Gary Dunny (University of Minnesota), Enterococcal PheromoneResponsive Plasmids: Broad-Host Range Transfer Controlled by Narrow-Host Range Cell-Cell Signaling

9:30am Patrick Keeling (University of British Columbia), Impact of Lateral Gene Transfer on the Eukaryotic Nuclear Genome

10:00am Break

10:30am Siv Andersson (University of Uppsala), Alpha-Proteobacterial Gene Transfers and the Origin of Mitochondria 

Columbia), Intracellular Gene Transfer in Endosymbiotic Genome Integration

11:30am-12:30pm Buffet Lunch, Dining Room

Session IV: Evolutionary Implications of LGT

\section{Chair}

$12: 45 p m$

$1: 15 \mathrm{pm}$

$1: 45 \mathrm{pm}$

$2: 15 \mathrm{pm}$

2:45pm

$3: 15 \mathrm{pm}$
Jonathan Eisen (The Institute for Genomic Research)

Jonathan Eisen (The Institute for Genomic Research), Environmental Genomics and LGT: Can we Identify Organisms through their DNA if all Organisms are Chimeras?

Sandra Baldauf (University of York), Inferring Eukaryotic Divergences

Patrick Forterre (University of Paris), How to Recover the History of the Archaeal Domain, despite Lateral Gene Transfer?

Ford Doolittle (Dalhousie University), "Web of Life"

Poster Abstract Presentation: M. Virginia Sanchez Puerta (University of Maryland-College Park), The Plastid Genome of the Haptophyte Emiliania Huxleyi and the Evolution of the Cholorphyll C Containing Plastids

Break

\section{Wrap-Up: Impact, Applications, Future Challenges}

$3: 45 \mathrm{pm}$

$4: 15 \mathrm{pm}$

$5: 15 \mathrm{pm}$
Claire Fraser (The Institute for Genomic Research), Comparative Microbial Genomics: Insights into Evolution and Organismal Diversity

Panel Discussion of major future intellectual/disciplinary/technical challenges for the field featuring speakers from Sessions III and IV

Buses leave Beckman Center for Hyatt Regency Newport Beach and Orange County Airport 
NAS SACKLER COLLOQUIUM

THE TAPESTRY OF LIFE: LATERAL TRANSFERS OF HERITABLE ELEMENTS

DECEMBER 12-13, 2005

BECKMAN CENTER OF THE NATIONAL ACADEMIES, IRVINE, CA

FINAL. PARTICIPANT ROSTER

\begin{tabular}{|c|c|c|c|}
\hline First Name & Last Name & Organization & Category \\
\hline Siv & Andersson & University of Uppsala & Organizer/Speaker \\
\hline Gemma & Atkinson & University of York & Student \\
\hline Holly & Atkinson & University of California, San Francisco & Student \\
\hline Peter & Atkinson & University of California, Riverside & General participant \\
\hline Jamie & Bacher & The Scripps Research Institute & Student \\
\hline Jonathan & Badger & The Institute for Genomic Research & General participant \\
\hline Sandra & Baldauf & University of York & Speaker \\
\hline Arthur & Beauregard & Wadsworth Center, NYS Department of Health & Student \\
\hline Robert & Beiko & The University of Queensland & Student \\
\hline Marlene & Belfort & Wadsworth Center, NYS Department of Health & Speaker \\
\hline Eva & Berglund & University of Uppsala & Student \\
\hline Peter & Bickel & University of California, Berkeley & General participant \\
\hline Melanie & Blokesch & Stanford University & Student \\
\hline Mya & Breitbart & San Diego State University & Student \\
\hline Bjorn & Brindefalk & University of Uppsala & Student \\
\hline Adriana & Briscoe & University of California, Irvine & General participant \\
\hline Roy & Britten & Caltech & General participant \\
\hline Yiping & Cao & University of California, Santa Barbara & Student \\
\hline Venkata & Chalamcharla & Wadsworth Center, NYS Department of Health & Student \\
\hline Viann & Chan & University of British Columbia & Student \\
\hline Casey & Chen & USC School of Dentistry & General participant \\
\hline Penny & Chisholm & Massachusetts Institute of Technology & Speaker \\
\hline Alex & Cohen & National Academy of Sciences & Staff/Press \\
\hline Joel E. & Cohen & Rockefeller \& Columbia Universities & Staff/Press \\
\hline Maureen & Coleman & MIT & Student \\
\hline R. Sidney & Cox & Caltech & Student \\
\hline Nicole & Creanza & Rockefeller University & Student \\
\hline Alyssa & Cruz & National Academy of Sciences & Staff/Press \\
\hline Peter & Dailey & Roche Molecular Diagnostics & General participant \\
\hline Aaron & Darling & University of Wisconsin-Madison & Student \\
\hline Audrey & de Koning & University of British Columbia & Student \\
\hline Patrick & Dennis & National Science Foundation & General participant \\
\hline Ford & Doolittle & Dalhousie University & Speaker \\
\hline Gary & Dunny & University of Minnesota & Speaker \\
\hline Jonathan & Eisen & The Institute for Genomic Research & Organizer/Speaker \\
\hline Brian & Federici & University of California, Riverside & General participant \\
\hline Patrick & Forterre & Institut de Génétique et Microbiologie & Speaker \\
\hline Claire & Fraser & The Institute for Genomic Research & Organizer/Speaker \\
\hline Francesca & Frentiu & University of California, Invine & Student \\
\hline Ken & Fulton & National Academy of Sciences & Staff/Press \\
\hline Sudhindra & Gadagkar & University of Dayton & General participant \\
\hline Arnold & Goodman & University of California, Irvine & General participant \\
\hline Jeffrey & Gordon & Washington University School of Medicine & Organizer/Speaker \\
\hline
\end{tabular}


NAS SACKLER COLLOQUIUM

THE TAPESTRY OF LIFE: LATERAL TRANSFERS OF HERITABLE ELEMENTS

DECEMBER 12-13, 2005

BECKMAN CENTER OF THE NATIONAL ACADEMIES, IRVINE, CA

FINAL PARTICIPANT ROSTER

\begin{tabular}{|c|c|c|c|}
\hline First Name & Last Name & Organization & Category \\
\hline Charles & Hall & Duke University Medical Center & Student \\
\hline Julia & Halo & Duquesne University & Student \\
\hline Craig & Herbold & University of California, Los Angeles & Student \\
\hline Emma & Hill & Public Library of Science & Staff/Press \\
\hline Erik & Hom & University of California San Francisco & Student \\
\hline William & Hsiao & Simon Fraser University & Student \\
\hline Jinling & Huang & University of Connecticut & Student \\
\hline William & Inwood & University of California, Berkeley & General participant \\
\hline Marcin & Joachimiak & University of California, Berkeley & Student \\
\hline Katherina & Kechris & University of California San Francisco & Student \\
\hline Patrick & Keeling & University of British Columbia & Speaker \\
\hline Eric & Knox & Indiana University & General participant \\
\hline Nakao & Kubo & Indiana University & Student \\
\hline Victor & Kunin & DOE Joint Genome Institute & Student \\
\hline James & Lake & University of California, Los Angeles & Speaker \\
\hline Morgan & Langille & Simon Fraser University & Student \\
\hline Jeffrey & Lawrence & University of Pittsburgh & Speaker \\
\hline Rachel & Lesinski & National Academy of Sciences & Staff/Press \\
\hline Ruth & Ley & Washington University School of Medicine & General participant \\
\hline Haiping & $\mathrm{Li}$ & Western Institute for Food Safety and Security & Student \\
\hline Miranda & Lim & Emory University & Student \\
\hline Michael & Mahowald & Washington University in St. Louis & Student \\
\hline Bob & Mau & University of Wisconsin-Madison & General participant \\
\hline Allison & McDonald & University of Toronto & Student \\
\hline Calvin & McLaughlin & University of California, Irvine & General participant \\
\hline Jeffrey $\mathrm{H}$. & Miller & University of California, Los Angeles & General participant \\
\hline Michael & Miller & Stanford University & Student \\
\hline Randall & Murch & Virginia Polytechnic Inst and State Univ & General participant \\
\hline Kenlee & Nakasugi & University of New South Wales & Student \\
\hline Patrick & O'Donoghue & University of Illinois at Urbana-Champaign & Student \\
\hline Han Chuan & Ong & Indiana University & Student \\
\hline Christos & Ouzounis & The European Bioinformatics Institute & Speaker \\
\hline Jeffrey & Palmer & Indiana University & Speaker \\
\hline Nicola & Patron & University of British Columbia & Student \\
\hline Kevin & Penn & TIGE & General participant \\
\hline Marty & Perreault & National Academy of Sciences & Staff/Press \\
\hline Herve & Philippe & University of Montreal & Speaker \\
\hline April & Phillips & University of California, Irvine & Student \\
\hline Nelida & Pohl & University of California, Irvine & Student \\
\hline Lita & Proctor & The Gordon and Betty Moore Foundation & General participant \\
\hline Guenola & Ricard & CMBI/NCMLS & Student \\
\hline Danny & Rice & Indiana University & Student \\
\hline Aaron & Richardson & Indiana University & Student \\
\hline
\end{tabular}


NAS SACKLER COLLOQUIUM

THE TAPESTRY OF LIFE: LATERAL TRANSFERS OF HERITABLE ELEMENTS

DECEMBER 12-13, 2005

BECKMAN CENTER OF THE NATIONAL ACADEMIES, IRVINE, CA

FINAL PARTICIPANT ROSTER

\begin{tabular}{|c|c|c|c|}
\hline First Name & Last Name & Organization & Category \\
\hline Maria & Rivera & University of California, Los Angeles & General participant \\
\hline Alberto & Roca & University of California, Irvine & Student \\
\hline Matthew & Rogers & University of British Columbia & Student \\
\hline Forest & Rohwer & San Diego State University & Speaker \\
\hline Abigail & Salyers & University of llinois at Urbana-Champaign & Speaker \\
\hline M. Virginia & Sanchez Puerta & University of Maryland-College Park & Student \\
\hline Suzanne & Sandmeyer & University of California, Irvine & General participant \\
\hline Daniel & Santillano & University of California, Merced & Student \\
\hline Jason & Schwarz & Rockefeller University & Student \\
\hline Jacqueline & Servin & University of California, Los Angeles & Student \\
\hline Kaiyuan & Shi & University of Connecticut & Student \\
\hline Melinda & Simmons & Gordon and Betty Moore Foundation & General participant \\
\hline Anne & Simonson & The Burnham Institute & Student \\
\hline Ryan & Skophammer & University of California, Los Angeles & Student \\
\hline Marc & Smith & University of Dayton & Student \\
\hline David & Soergel & University of California, Berkeley & Student \\
\hline Rob & Steele & University of California, Irvine & General participant \\
\hline Diane & Sullenberger & PNAS & Staff/Press \\
\hline Fumihiko & Takeuchi & Juntendo University & General participant \\
\hline George & Todaro & Targeted Growth, Inc. & General participant \\
\hline Peter & Turnbaugh & Washington University in St. Louis & Student \\
\hline Jacob & Waldbauer & MITMHOI & Student \\
\hline Hans & Wildschutte & University of Pittsburgh & Student \\
\hline Dongying & Wu & The Institute for Genomic Research & General participant \\
\hline Martin & Wu & The Institute for Genomic Research & General participant \\
\hline Shurong & Xiang & University of California, Santa Barbara & Student \\
\hline Gregory & Young & Indiana University & Student \\
\hline Anthony & Zuccarelli & Loma Linda University & General participant \\
\hline
\end{tabular}


114 Colloquium Participants

\begin{tabular}{|c|c|c|c|c|c|}
\hline $\begin{array}{c}\text { Number of } \\
\text { Students }\end{array}$ & $\begin{array}{c}\text { Number of } \\
\text { Postdocs }\end{array}$ & $\begin{array}{c}\text { Number of } \\
\text { Female } \\
\text { Participants }\end{array}$ & $\begin{array}{c}\text { Number of Male } \\
\text { Participants }\end{array}$ & $\begin{array}{c}\text { Number of } \\
\text { institutions }\end{array}$ & $\begin{array}{c}\text { Number of } \\
\text { represented } \\
\text { countries }\end{array}$ \\
\hline \hline $59(52 \%)$ & $14(24 \%)^{*}$ & $41(36 \%)$ & $73(64 \%)$ & 56 & 8 \\
\hline
\end{tabular}

Represented Countries
United States
Canada
United Kingdom
Australia
Sweden
France
Japan
Netherlands

Top 5 United States Institutions

University of California, Irvine Indiana University

University of California, Los Angeles

The Institute for Genomic Research

Washington University in St. Louis

\section{Canada}

University of British Columbia

Simon Fraser University

Dalhouise University

University of Montreal

University of Toronto
United Kingdom

University of York

European Bioinformatics Institute

France

Institut de Génétique et Microbiologie

\section{Australia}

The University of Queensland University of South Wales

Japan

Juntendo University
Sweden

University of Uppsala

\section{Netherlands}

Center for Molecular and

Biomolecular Informatics/Nijmegen

Centre for Molecular Life Sciences

$24 \%$ of students are postdocs

$12 \%$ of participants are postdocs 